\title{
Students Algebraic Thinking Processes in Mathematics Problem Solving at Low Mathematic Ability Student Based on Quantitative Reasoning Ability
}

\author{
Dewi Purnama Sari ${ }^{1, a)}$, Feny Rita Fiantika, M.Pd. ${ }^{2)}$ \\ Universitas Nusantara PGRI Kediri \\ Jalan K.H. Ahmad Dahlan Nomor 76, Mojoroto, Kediri 64129, Indonesia \\ a)email : dewigitapurnama@gmail.com
}

\begin{abstract}
Quantitative Reasoning is students ability on conclused a problem solved. The purpose of this research has information about algebraic thinking processed on student with low ability based on Quantitative Reasoning ability. Methods used qualitative descriptive with purpose for desription about algebraic thinking processed on mathematic problem solving basic material on function with low ability of student based on quantitative reasoning ability. This paper used algebraic ability paper tes and interview transcript. Subject cluster used purposive technic with apretiation high value on raport and teacher review which known about students characteristic. The results showed that algebraic thinking processed on mathematic problem solving on student with low ability based on quantitative reasoning ability obtained Less category because subject didn't capable used deductive reasoning on clarify $n$ symbol on problem solved and representation on arrow diagram and cartesius diagram for the first test. That result showed Quantitative Reasoning subject on analyzed problems to extract and quantify essential features with deductive reasoning obtained "Less" category. The second test, subject didn't capable used inductive reasoning on conclude highest bounce of the ball from the graph and function table. That result showed Quantitative Reasoning subject on analyzed problems to extract and quantify essential features with inductive reasoning obtained "Less" category.
\end{abstract}

Keywords: algebraic thinking processed, function material, low mathematic ability, quantitative reasoning ability.

\begin{abstract}
Abstrak. Quantitative Reasoning merupakan kemampuan siswa dalam menyimpulkan suatu permasalahan. Tujuan dari penelitian ini adalah untuk mengetahui lebih mendalam mengenai proses berpikir aljabar terutama pada siswa dengan kemampuan rendah ditinjau dari kemampuan Quantitative Reasoning. Metode penelitian adalah deskriptif kualitatif dengan tujuan untuk mendeskripsikan proses berpikir aljabar siswa dalam penyelesaian masalah matematika materi fungsi pada siswa kemampuan rendah ditinjau dari kemampuan quantitative reasoning. Instrumen dalam penelitian ini adalah lembar tes kemampuan berpikir aljabar dan lembar wawancara. Pemilihan subjek dilakukan secara purposive dengan mempertimbangkan nilai rapor tertinggi dan pertimbangan guru kelas yang lebih mengetahui karakteristik siswa. Hasil penelitian menunjukkan bahwa proses berpikir aljabar dalam penyelesaian masalah matematika siswa kemampuan rendah ditinjau dari kemampuan quantitative reasoning memperoleh kategori kurang karena subjek belum mampu menggunakan penalaran deduktif dalam menjelaskan makna simbol $n$ dalam permasalahan dan merepresentasikan dalam diagram panah dan diagram cartesius pada soal nomor satu sehingga memperoleh kategori kurang. Subjek juga belum mampu menggunakan penalaran induktif dalam menyimpulkan lambungan tertinggi bola berdasarkan tabel fungsi yang diperjelas dengan grafik fungsi pada soal nomor dua.
\end{abstract}

Kata kunci: proses berpikir aljabar, fungsi, kemampuan matematika rendah, kemampuan quantitative reasoning. 


\section{INTRODUCTION}

Education is human effort to develop appropriate personality with culture and points on daily activities to be able encounter every changed because of advancement science and technology existence (Habibi, Darhim, Turmudi, 2018). Sumardyono (2004: 28) clarified objective on mathematics education emphasized on student was skill for capable applicable mathematics to mathematical problem solving, other study or another problem which is related with daily activities. It is show that important skill for student elaboration is problem solving ability.

Problem solving ability could has support student to development and solved about mathematics problem which is appeared on daily activities or mathematical problem on other knowledge level. Problem solving stages applied in this research was Polya problem solving stages. These stages included : 1) understanding the problem, 2) devising a plan, 3) carry out a plan 4) looking back the conclusion (2004: 5). Polya problem solving stages application on learning process expected to students could have solved about problem which is constitute development of previous example accord applied working out proprietary problem on accord student ability.

In most of the daily activities we have found some aspects of algebraic thinking. Ameron (2002: 4) clarified algebraic thinking was mental processes like reasoning with unknowns, generalizing and formalizing relations between magnitudes and developing the concept variable') and algebraic symbolizing (symbol manipulation on paper). Algebraic thinking according by Herbert and Brown (1997:123) is using mathematical symbols and tools to analyze different situations by 1) extracting information from a situation, 2) representing that information mathematicallly in words, diagrams, tables, graphs, and equations, 3) interpreting and applying mathematical findings, such as solving for unknowns, testing conjectures, and identifying functional relationships to the same situation and to new related situation. According to the Kieran (2004: 142) Algebraic thinking could be interpreted as an approach to quantitative situations that emphasizes the general relational aspects with tools that are not necessarily letter-symbolic but which can ultimately be used as cognitive support for introducing and for sustaining the more traditional discourse of school algebra.

Some of definition showed with algebraic thinking students carry out an activities on effort analyze, representation, and make generalizing to symbols, pattern's and numbers which is represented by words, tables, images, diagrams and mathematics expressions. According to Berg (2009: 275) on title research " Developing Algebraic Thinking In A Community Of Inquiry" showed that participants research development of algebraic thinking were deeply interwoven with the processes related to the creation and development of the community of inquiry. Algebraic thinking has some component include algebra as mathematical thinking tools such as problem solving skills, representation skills, and quantitative reasoning skills, and algebra as fundamental algebraic ideas such as generalized arithmetic, the language of mathematics, and a tool for functions and mathematical modelling. Beside that, almost of students have problems on algebraic thinking processed on functional materials such as 1) arithmetic operation working out problems, 2) interpreted and understood symbols problem, 3) representation the situation as functional graphs problem. Properly, students must acquire both competencies that is problem solved ability and algebraic thinking ability in order to has full algebraic thinking understanding.

Reasoning is thinking processed on conclusion withdraw processed (Sumarno, 2013: 148). It has two kind are inductive reasoning and deductive reasoning. Conclusion withdraw based on some problem or limited pattern of problems is unductive reasoning. Beside that conclusion withdraw 
based on unanimously rules is deductive reasoning. Quantitative reasoning on mathematic is ability which is capable development on mathematic learning to analyze quantitative information and determine problem solving and procedure could be applied on certain problem to obtain a conclusion. Quantitative reasoning for basicly or objective value focused on problem solving. It is include six ability : 1) read and comprehenly information on many patterns, 2) interpretation quantitative information and make representation for conclusion, 3) used arithmetic problem solving, algebra, geometry, and statistic method, 4) estimate the answer and investigate advisability, 5) communicate quantitative information, and 6) make a definition from mathematic or statistic method.

Quantitative reasoning on algebra according Kaput \& Blanton (2005: 99) were "Algebraic reasoning is a process in which students generalize mathematical ideas from a set of particular instances, establish those generalizations through the discourse of argumentation, and express them in increasingly formal and age-appropriate ways". Quantitative reasoning on algebra emphasized conclusion withdraw based on datas or quantitative information. This reasoning was important because is the greatest way to solved many type for problem solving. Quantitative reasoning on algebra could help students to understood and development concepts on algebra representation, analyzed problems to extract and quantify essential features on deductive or inductive reasoning.

Based on background, researcher was interest to arranged research with title "Students Algebraic Thinking Processed In Mathematic Problem Solving At Low Mathematic Ability Student Based On Quantitative Reasoning Ability". This research aim to aims to analyze algebraic thinking processed in mathematic problem solving by low mathematic ability based on quantitative reasoning ability.

\section{RESEARCH METHODS}

This research was conducted by using qualitative approach with descriptive method. The subjects of this research were three students who has high mathematic ability, intermediate mathematic ability, and low mathematic ability that was chosen by purposive sampling technique on three category from mathematic raport and teacher reviews which know more about students characteristic. They were from SMP Plus Rahmat Kediri. The source for this research was algebraic thinking test result with compability from the indicator sheet and direct interview with questionnaire. From subject, researcher could analysed and identify to presented in the form of a algebraic thinking description. Algebraic thinking processed were elaborated to be three indicator, such as explain in the Table Caption 1.

Table Caption 1. Modification indicator of algebraic thinking

\begin{tabular}{|c|c|c|}
\hline No. & Component & Indicator \\
\hline \multirow[t]{2}{*}{1.} & \multirow{2}{*}{$\begin{array}{l}\text { Problem Solving } \\
\text { Skills }\end{array}$} & Using problem solving strategies. \\
\hline & & Exploring multiple approaches or multiple solutions. \\
\hline \multirow[t]{4}{*}{2.} & \multirow[t]{4}{*}{ Representation Skills } & $\begin{array}{l}\text { Displaying relationships, visually, symbolically, numerically, } \\
\text { verbally. }\end{array}$ \\
\hline & & Translating among different representations. \\
\hline & & Interpreting information within representations. \\
\hline & & $\begin{array}{l}\text { Representing mathematical ideas using equations, tables, } \\
\text { graphs, or words. }\end{array}$ \\
\hline \multirow[t]{2}{*}{3.} & \multirow{2}{*}{$\begin{array}{l}\text { Quantitative } \\
\text { Reasoning Skills }\end{array}$} & Analyzing problems to extract and quantify essential features. \\
\hline & & Inductive and deductive reasoning. \\
\hline
\end{tabular}


Instrument for this research were algebraic test paper and transcrip of interview which is completed of validation for specialist instructor from university and mathemathic teacher. The next steps to take a specimen of students who study carefully before it to found validity and reability for the instrument. The conclusion used triangulasi (Patton, 1999: 1193) until obtained a really valid data.

\section{RESULTS AND DISCUSSION}

\section{Analyzed Test For Algebraic Thinking In Mathematic Problem Solving By Low Student Ability Based On Quantitative Reasoning Ability.}

1. The first algebraic thinking test.

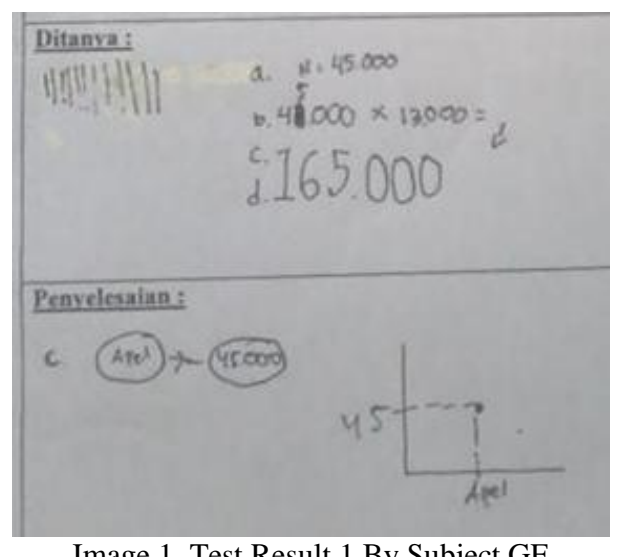

Image 1. Test Result 1 By Subject GF

\begin{tabular}{|c|c|c|}
\hline $\mathbf{P}$ & : & $\begin{array}{l}\text { Now see your answer for 1a. The question, how many apples were obtained if } \\
\text { you have Rp. } 45,000,- \text {. And if on the paper was already knew the price of } 1 \text { apple } \\
\text { was Rp. } 5,000,- \text {. What about your settlement? }\end{array}$ \\
\hline GF & : & Um ... It's means 45000 divided by 5000, ma'am. Then the answer ..... ?? \\
\hline $\mathbf{P}$ & : & $\begin{array}{l}\text { Look, why here (pointed to the subject answer sheet) } 45000 \text { multiplied by } 13000 \\
\text { ?? }\end{array}$ \\
\hline GF & : & Hheheee.... Yes ma'am, I was still confused ....... \\
\hline $\mathbf{P}$ & • & your answe \\
\hline GF & : & am, that means for number $1 \mathrm{~b}$ must be 5000 multiplied by 13 apples, \\
\hline $\mathbf{P}$ & : & $\begin{array}{l}\text { ttely. On 1a problem, the question was how many } n \text { apples gain? What } \\
\text { g of } n \text { on this problem ?? }\end{array}$ \\
\hline GF & : & $\mathrm{m}$ \\
\hline $\mathbf{P}$ & : & $\mathrm{n}$ meaning how many apples \\
\hline GF & : & \\
\hline $\mathbf{P}$ & : & \\
\hline GF & : & \\
\hline $\mathbf{P}$ & : & $\begin{array}{l}\text { It's not that!! Remember, we represented arrows diagram with the points on the } \\
\text { lines, you know ?? }\end{array}$ \\
\hline GF & : & $\mathrm{U}$ \\
\hline $\mathbf{P}$ & : & $\begin{array}{l}\text { learned the set, comprehend of the function. We make } \\
\text { id you remember?? }\end{array}$ \\
\hline GF & & $\begin{array}{l}\text { Umm... Did you mean the arrow diagram, set sequential pairs and cartesius } \\
\text { diagram? }\end{array}$ \\
\hline & & you could explain your solution to the number $1 \mathrm{c}$ problem? \\
\hline
\end{tabular}


GF : Um ........... (smiling and shaking his head)

Image 2. Interview Transcrip Of Subject GF

Algebraic thinking test for number one showed, subject didn't capable to solved with suitable problem solving steps used function formula because subject didn't comprehend with the problem. The calculation which is subject appeared untrue. Subject didn't capable on clarify $n$ symbol on problem solved and representation on arrow diagram and cartesius diagram which refer a relation between apple quantity and apple cost. Subject didn't wrote the solved on answer paper too. Beside that, interview transcipt showed subject didn't capable to comunicated a steps of problem solved. It was showed that subject didn't capable used deductive reasoning on clarify $n$ symbol on problem and representation on arrow diagram and cartesius diagram for the first problem test. The result that Quantitative Reasoning subject on analyzing problems to extract and quantify essential features with deductive reasoning obtained "Less" category.

2. The second algebraic thinking on problem solving test.

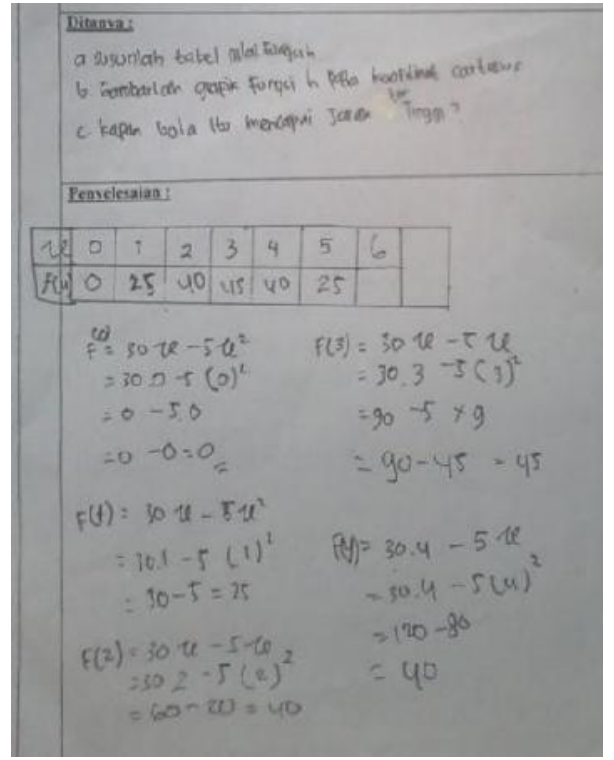

Image 3. Test Result 2 By Subject GF

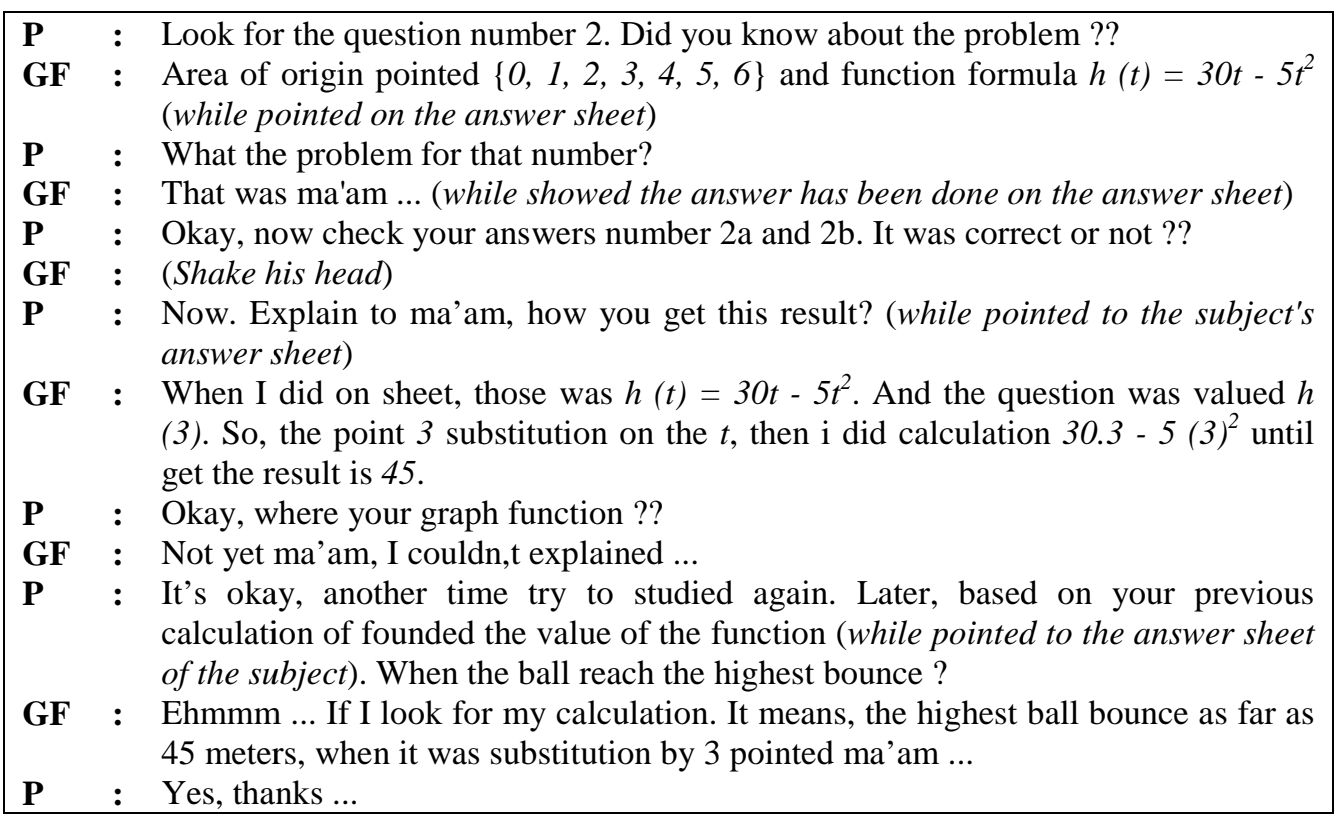

Available online at Journal homepage: ejournal.iainkerinci.ac.id/index.php/edumatika Email: edumatika@iainkerinci.ac.id 
Image 4. Interview Transcript Of Subject GF

Algebraic thinking test for number two showed subject didn't capable to understood about the problem on paper. Subject didn't communicated about a steps for problem solved when subject interviewing. Subject try to make a function table with function calculate value. It was mean subject replaced value of $t=0$ until $t=6$ on function formula which is available on paper eventhough didn't make a graph for the last solved problem. Beside that, on interview transcript subject didn't verified to representation on graph clearly which is graph function of $h(t)=30 t-5 t^{2}$ could clarified to make a conclusion about highest bounce of the ball. It was showed subject didn't capable used inductive reasoning on conclude highest bounce of the ball from the grapich and function table. With the result that Quantitative Reasoning subject on analyzing problems to extract and quantify essential features with inductive reasoning obtained "Less" category.

\section{CONCLUSION}

Based on each percentage of achievement by algebraic thinking test and questionnaire with some descriptive achievement from the test, it could be concluded that algebraic thinking processed by low mathematic ability based on quantitative reasoning ability obtained Less category because subject didn't capable used deductive reasoning on clarify $n$ symbol on problem solved and representation on arrow diagram and cartesius diagram for the first algebraic thinking test. So, the result that Quantitative Reasoning subject on analyzing problems to extract and quantify essential features with deductive reasoning obtained "Less" category. The second algebraic thinking test, subject didn't capable used inductive reasoning on concluded highest bounce of the ball from the graph and function table. So, the result that Quantitative Reasoning subject on analyzing problems to extract and quantify essential features with inductive reasoning obtained "Less" category. The percentage of algebraic thinking test for GF subject was 35 .

\section{ACKNOWLEDGMENTS}

The author would like to said thanks for a student and mathematic teacher who help on get the data for this research. The highest appreciation has presented to lecturer Ms. Feny Rita Fiantika, M.Pd., that have guided researcher from beginning research until the completion of this article.

\section{REFERENCES}

Ameron, Barbara Ann Van. 2002. Reinvention Of Early Algebra. Tesis. Nederlands: Universiteit Utrech.

Arikunto, Suharsimi. 2013. Dasar-dasar Evaluasi Pendidikan. Jakarta: PT. Bumi Aksara.

Berg, Claire Vaugelade. 2009. Developing Algebtaic Thinking In Community Of Inquiry. Disertasi. Tidak dipublikasikan. University of Agder press.

Blanton, M.L., Kaput, J.J. (2005). Functional Thinking as a Route Into Algebrain the Elementary Grades. International Reviews on Mathematical Education, 37(1), 34-42.

Carroll, J. B. (1993). Human cognitive abilities: A survey of factor-analytic studies. Cambridge, England: Cambridge University Press.

Herbert, Kristen and Rebecca H.Brown. 1997. Patterns as Tools for Algebraic Reasoning. NCTM School-Based Journal. (Online), http://sdcounts.tie.wikispaces.net/file/view/Pattersn+as+tools.pdf/ 
Pattersn+as+tools.pdf, diunduh 7 Mei 2016.

Habibi, M, Darhim, Turmudi (2018). Self-Determination in Mathematics Learning Process by Using Generative Multi-Representation Learning (GMRL) Model. Journal Physic: Conference Series. 1097012155.

Ibad, Misbahul. 2011. Eksperimentasi Pembelajaran Matematika Metode Kooperatif Tipe Students Teams Achievement Divisions dan Metode Kooperatif Tipe Numbered Heads Together Ditinjau Dari Gaya Belajar Siswa. Surakarta: perpustakaanuns. ac.id.

Kieran, Carolyn. 2004. What Is Algebraic Thinking. Du Quebee A Montreal University. Volume 8 Nomor $\quad 1 . \quad$ (Online), tersedia: http://math.nie.edu.sg/ame/matheduc/tme/tmeV8_1/Carolyn\%20Kieran.pdf, diunduh 7 Mei 2016.

Kriegler, Shelley. 2007. Just What Is Algebraic Thinking. Departement Of Mathematics: UCLA. (Online), tersedia: kriegler@ucla.edu, diunduh 7 Mei 2016.

Lie, Anita. 2009. Kooperatif Learning. Jakarta: Gramedia.

Lins, R.C. 1992. A Framework For Understanding What Algebraic Thinking Is. Tesis. Tidak Dipublikasikan. University of Nottingham.

Moleong, Lexy J. M.A. 2012. Metodologi Penelitian Kualitatif. Bandung: PT.Remaja Rosda Karya.

Polya, G. 2004. How To Solve It. A New Aspect Of Mathematical Method. Stanford University.

Qur'ani, ZW. 2015. Analisis Kemampuan Berpikir Aljabar Siswa Pada Materi Sistem Persamaan dan Pertidaksamaan Linier. Skripsi. Tidak dipublikasikan. Surabaya: UINSurabaya.

Radford, Luis. 2006. Algebraic Thinking And The Generalization Of Patterns: A Semiotic Perspective. Universite Laurentiene. Volume 1-2. (Online), tersedia:http://www.luisradford.ca/pub/60_pmena06.pdf, diunduh 29 Mei 2016.

Sabirin, M. 2014. Representasi dalam Pembelajaran Matematika. Jurnal Pendidikan Matematika IAIN Antasari, 1(2): 33-34.

Slavin, RE. 1995. Coperative Learning: Theory, Research and Practice Second Edition. Boston: Allyn and Bacon Publisher.

Sumardyono. 2004. Karakteristik Matematika dan Implikasinya Terhadap Pembelajaran Matematika. Yogyakarta: Depdiknas.

Sumarmo, U. (1987). Kemampuan Pemahaman dan Penalaran Matematika Siswa dikaitkan dengan Kemampuan Penalaran Logik Siswa dan Beberapa Unsur Proses Belajar Mengajar. Disertasi pada PPs UPI Bandung: tidak diterbitkan.

Sumarmo, U. (2013). Berpikir dan Disposisi Matematik serta Pembelajarannya: Kumpulan Makalah. Jurusan Pendidikan Matematika, UPI, Bandung.

Undang-undang Republik Indonesia. Nomor 20 Tahun 2003. Tentang Sistem Pendidikan Nasional Dan Keputusan Menteri Pendidikan Nasional Tentang Dewan Pendidikan Dan Komite Sekolah. Biro Mental Spiritual Pemerintah Provinsi Jawa Timur 